\title{
IQ Test Expert System for Selecting Candidates for New Students
}

\author{
Mawaddah Arrosty ${ }^{1}$, Jijon Raphita Sagala ${ }^{2}$ \\ Informatics Engineering Study Program, STMIK Pelita Nusantara, Jl. St. Iskandar Muda No. 1 \\ Medan, North Sumatra, Indonesia 20154
}

E-mail: Mawaddaharrosty@gmail.com

\begin{abstract}
The IQ test information system at the Taman Siswa Lubukpakam Private High School is still done by selling, after the which Recapitulation is done manually, the obstacle is that the school has Difficulties in delivering information on the results of IQ tests that are slow and not timely, and in the calculation of the IQ test results that require a long time, the resulting in slow work. The making of this system uses the methodology of field researchers, interviews and observations. This requires some Data Including student data. Data Reviews These are expected to be the basis of making this application system in order to present the required information quickly intervening and accurately. IQ tests in the determination and consideration of class Unmatched in schools are usually done manually and the make enough time to find out the IQ results in Determining prospective new students at school, besides calculating the IQ test results Because it is quite complicated, then to Facilitate the school in carrying out the IQ test to Determine the prospective new students required the existence of a computer-based application and to build applications that will be used by the web programming language. The results of the evaluation of the application that was built were very helpful and accelerated the school in Determining the selection of classrooms that adjusted Reviews their abilities and civilized the use of computers among students. then to Facilitate the school in carrying out the IQ Test to Determine the prospective new students required the existence of a computer-based application and to build applications that will be used by the Web programming language. The results of the evaluation of the application that was built were very helpful and accelerated the school in Determining the selection of classrooms that adjusted Reviews their abilities and civilized the use of computers among students. then to Facilitate the school in carrying out the IQ Test to Determine the prospective new students required the existence of a computer-based application and to build applications that will be used by the Web programming language. The results of the evaluation of the application that was built were very helpful and accelerated the school in Determining the selection of classrooms that adjusted Reviews their abilities and civilized the use of computers among students.
\end{abstract}

Keywords: IQ Test Class Selection, Web

\section{Introduction}

Computer technology is advanced computational calculation system developed with smart devices to facilitate the work of man. Computerization is an electronic device that can be used as a data processing function. All data are processed within the existing computer procedure based formula. So this technology is needed of the school to process the data that will be used in selecting a new student IQ tests to determine the class election. The tests used a variety of the school, with students' ability IQ different school then perform tests to determine grade. IQ tests are usually done manually happened keterlambaran school in knowing the test results. In addition, many schools difficult to calculate because the test results were quite complicated. With direct discussions along with school principal and teaching staff, it was found that very fundamental priority issues where faculty have difficulty in selecting the appropriate grade students' abilities. The development of technology, the researchers in this case would like to promote the election of prospective new students for grade determination to a computer-based test is based on an IQ test and how to design an application that IQ tests manually move into digital or computer-based system. This device is made to determine the student's ability to determine the class. From research on each gave an input in the development of an IQ test well academically high school students, utilization of the Internet, and the use of IQ tests in the development of the personality test.

\section{Theory}

\subsection{Expert system}

a. Understanding Expert System 
According Irham Cahya Nugraha and Herlawati (2016: 2), Expert System is a computer-based application that is used to resolve the issue as may be thought by experts. Troubleshooting system that normally can only be solved by an expert, as did an expert successful when able to take the original decision both in terms of decision-making processes and decision obtained.

Advantages of the use of expert systems are:

1) Allows a user who is not an expert in a particular field can do the work of an expert.

2) Can do the same process is repeated.

3) Increase productivity. Expert systems can work faster than humans. These advantages mean reducing the number of workers needed, and ultimately reduce costs.

4) Preparing expert advice can reduce the error rate.

5) Make the equipment easier dioprasikan because experts can train inexperienced workers.

6) Experts can not be tired or bored. Also consistent dala member answers and always members full attention.

7) As a complement to the training media.

b. Expert System Structure

According Lempao (2011: 2), Nurmala According to Anik Andriani (2016: 14), expert systems have a major component in the structure, namely:

1) The knowledge base (Knowledge Base)

The core of an expert system is a knowledge base which is a representation of the knowledge possessed by an expert who is composed of facts and rules. The fact is the information about objects, events, and circumstances. While the rule is a way to bring new facts based on facts that already exist and are known. Can we find a knowledge base directly from an expert or from historical data which contains data the knowledge of an expert.

2) The inference engine (Inference Engine)

The brain of the expert system is an inference engine that serves to the reasoning process towards a state based on the available knowledge base. In the case an inference engine to manipulate and direct the process of rules, models, and the fact that is stored in the knowledge base in order to achieve a solution or conclusion.

c. Knowledge Base (Knowledge Base)

According to Nita Merlina and Rahmat Hidayat in his book Expert System Design (2012: 4), the expert system also has disadvantages such as:

1) The cost required to create maintain and develop an expert system that is very expensive.

2) It will be difficult to extract from human expertise.

3) Approaching an expert on an assessment of the situation may be different, but it's true.

4) It's hard for a high caliber experts to summarize a good assessment of the situation at the time under pressure of time.

5) An expert has the right answer does not know if there are conflicts that occur outside of the rule.

d. Knowledge representation

According Hartati, Iswanti Irham Cahya Nugraha and Herlawati (2016: 2), Knowledge Base (Knowledge Base) is the result of the acquisition and representation of knowledge from an expert. The knowledge base contains insights in problem solving. There are two forms of knowledge bases that are commonly used, namely:

1) Rule Based Reasoning (Rule Based Reasoning) is represented using the knowledge of the rules of the form: If-Then. This reasoning is used if there are a number of expert knowledge on a particular problem, and experts can carry out settlement sequentially.

2) Case-Based Reasoning (Cased Based Reasoning) is a knowledge base will contain solutions that have been achieved before, then lowered a solution to the current situation.

\subsection{Forward Chaining method}

Forward Chaining method is search techniques to data-driven future that starts with an object and the incorporation of some rules to produce a conclusion or goal. Tracking is very good future if researchers with the problems that began with the initial information data and the final settlement to be achieved, because the whole process will be done sequentially advanced. Forward chaining is a sequencing process that begins by displaying the data gathering ata facts that convincingly towards the final conclusion. So the data according to the situation is true, then the process will be stated conclusions. Forward chaining as inference starts with the new information available and obtained the opinion. If an application generates true that not in, then use a forward chaining.

Steps - steps for creating an expert system using a forward chaining method, namely:

1) Pendefenisan problem starts with the selection and acquisition pengatahuan problem domain.

2) Dendefenesian input data to start the inference as required by forward chaining system.

3) Pendefenisian data control structure to help control the activation of a rule. 
4) Writing code pengatahuan early in the domain.

5) Testing the system in order to know the extent to which the system is running.

6) The design of the interface with the base pengatahuan.

7) Development of the system.

8) Evaluation system.

As examples of the basic theory in the completion of forward chaining method, namely:

To facilitate understanding of this method, be granted illustrative case of making an expert system with the following rules:

And R1 = operator display systems, Then enter student data.

And students $\mathrm{R} 2$ = operator, Then To register.

R3 = students And display systems, Then register.

And displays R4 = student registration, Then display the test.

$\mathrm{R} 5=$ display test And displaying a score, Then look at the score and explanation.

R6 $=$ see the scores and information Then report the test results.

Rule simplification:

$\mathrm{R} 1=\mathrm{A} 1$ And $\mathrm{A} 3, \mathrm{~A} 4$ then.

$\mathrm{R} 2=\mathrm{A} 1$ And A2, Then A5.

$\mathrm{R} 3=\mathrm{A} 2$ And A3, A5 then.

$\mathrm{R} 4=\mathrm{A} 2$ and $\mathrm{A} 6, \mathrm{~A} 7$ Then.

And A8 R5 = A7, then A9.

Then R6 = A9 A10.

1. Solutions with Forward Chaining as follows:

Step 1: IF A1 And A3, A4 Then = R1

Step 2: IF A2 And A3 A1, A2, A3 -> True = R3

Step 3: IF A2 And A6, A7 Then A2, A3, A4, A5, A6, A7 -> True = R4

Step 4: IF A1 Then A5 A1, A2, A3, A4, A5 -> R2

Step 5: IF A7 And A8, A9 Then A1, A2, A3, A4, A5 -> True R5

Step 6: IF A9 Then A10, A10-> True

2. Forward chaining reasoning process shown in the figure below:

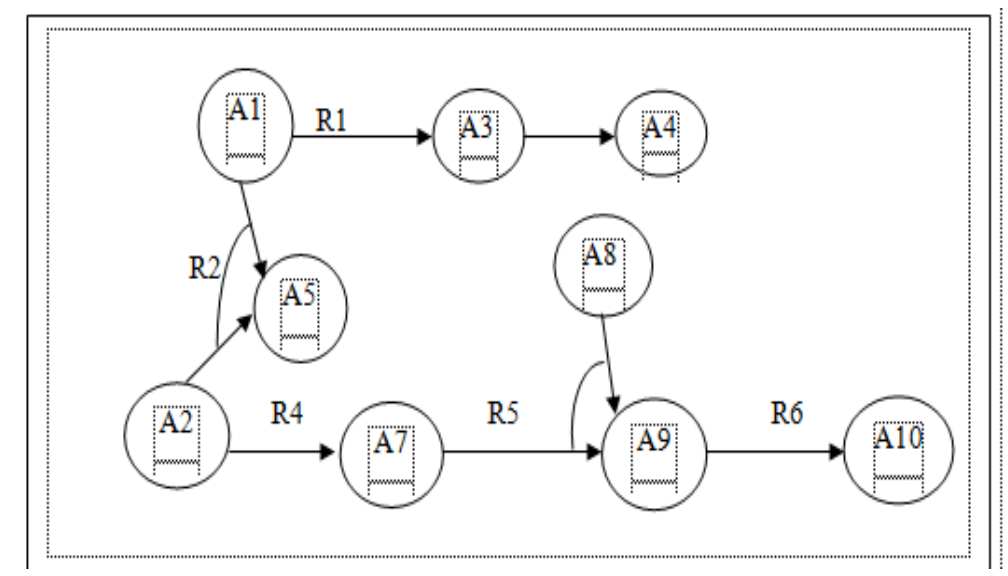

Figure 1. Tree Reasoning Forward Chaining

\section{2 probability}

Probability is the chance or probability of an event, happening or not and some great possibilities these events likely to occur. Probabilities are stated to have a value of 0 to 1 , or in an event. Probability is a quantitative way of dealing with the uncertainty that has existed since centuries 1 . The theory of probability is known by pascal fermal in 1654 .

As for the nature of probability as follows:

$$
0 \leq P A \leq 1
$$

The symbol $\mathrm{P}$ is used to value the probability of an event. Thus $\mathrm{P}(\mathrm{A})$ represents the probability of event A will occur in a single experiment. Smallest probability value is 0 . This value mungikin declared an event does not occur and the highest probability value is 1 declare an event that would happen. 
There are several concepts for defining probability and determine probable values, namely:

1) Classical approaches suggested in the many events that will be happening. Each event has a similar incident to occur.

The following classical probability formula:

Many outcome meets A, many outcomes overall.

$$
P A=\frac{\text { banyak outcome memenuhi } A}{\text { banyak outcomes keseluruhan }}
$$

2) Relative approach is an approach probabiltas values determined on the proportion of the possibility of a trial, there is no assumption of the equality of opportunity, because the determination of the values of probability based on observation and collection of data. The concept of relative frequency of an experiment carried out $\mathrm{n}$ times, event $\mathrm{A}$ is observed $\mathrm{f}$ times, then the formula:

$$
P A=\frac{f}{n}
$$

3) Subjective approach is determining the exact value of the probability that if only the events that happened in one incident. With the approach of an occurrence probability value is determined based on the level of trust that is individuals with grounded in a user has.

\subsection{Stages Case Intelligence}

a. Intelligence

According to Alfred Binet (1857-1911), Theodore Simon and EN Tamatjita, M Ardiana Irawati, Rio Ramdhani (2016: 1), intelligence consists of three components, namely the ability to direct our thoughts or actions ability to change the course of action when action was done, and the ability of self-criticism (autocritiism).

\section{b. measurement of Intelligence}

According to EN Tamatjita, M Ardiana Irawati, Rio Ramdhani (2016: 1), Intelligence Binet-Simon gets conceptual contribution of William Stern, about the concept of Intelligence Qoutient (IQ), which eventually led to the formula to find the level of intelligence a person with merasiokan mental age (Mental age) with chronological age (Chronologikal age), directed by IQ. Furthermore, well-known theories about this IQ up to now and is still widely used by scholars to search for a person's intelligence level [8]. Wiulliam Stern made the concept that there is a ratio between chronological age, the IQ formula as follows:

Intelligence Qoutient $=\frac{\text { MentalAge }}{\text { ChronologikalAge }} \times 100$

The calculation formula always results in decimal digits. To menjasikan round numbers, the result must be multiplied by 100 , so that the formula becomes:

$$
\left(I Q=\frac{M A}{C A} x 100\right)
$$

Examples: for example, students at the age of 15 years have had the intelligence of the average teenager who just entered the high school level it is 16 years old. This is called the age of the students Mental.berapakah IQ?

$$
I Q=\frac{16}{15} \times 100=1.06 \times 100=106
$$

Interpretation or interpretation of IQ is as follows: 
Table 2.

IQ scores

\begin{tabular}{ll}
\hline The Intelligence & IQ \\
\hline Genius & Above 140 \\
very Super & $120-140$ \\
Super & $110-120$ \\
Normal & $90-110$ \\
Stupid & $80-90$ \\
frontier & $70-80$ \\
Moron / Dungu & $50-70$ \\
imbecile & $25-50$ \\
idiot & $0-25 \mathrm{~N}$ \\
\hline
\end{tabular}

Source: Arif Rahman Faithful, Loyal Wardani, and Muhammad Fairuzabadi, 2018

\section{Conclusion}

From research conducted at Private High School Student Park Lubukpakam can be concluded as comparisons which ultimately may provide improvements in the times to come.

The conclusions obtained are as follows:

a. IQ test process at Private High School Student Park Lubukpakam still not using a computerized system for testing is still done daily. So that the IQ test is slower and requires that long to find out the score.

b. IQ test system design at Private High School Student Park Lubukpakam using applications built with Sublime Text 3. Design table using MySQL as the database and presentation of student data.

c. The design of this test form that is made in this application is the form that contains the tests that have been directing the students, whether tend to be more exact control of matters or matters of exact. From this test match was a student in one class in the school.

\section{Reference}

[1] Arif Setia Rahman, Setia Wardani, dan Muhammad Fairuzabadi, "aplikasi simulasi test iq berbasis web mobile", Fakultas Teknik, Universitas PGRI Yogyakarta, 2018

[2] Ahyuna, dan Irmawati, " Perancangan Aplikasi Tes Iq Siswa Untuk Pertimbangan Pemilihan Jurusan Dengan Metode Forward Chaining", STMIK Dipanegara Makassar, 2016

[3] Anik Andriani, M.Kom, " Pemograman Sistem Pakar", Teknik Informatika, Yogyakarta, 2016

[4] Achmad Solichin, S.Kom, "Program Web Dengan Php Dan Mysql", Universitas Budi Luhur, Jakarta, 2010

[5] Feri Fahrur Rohman, dan Ami Fauzijah, "Rancang Bangun Aplikasi Sistem Pakar Untuk Menentukan Jenis Gangguan Perkembangan Pada Anak", Yogyakarta, 2010

[6] Irham Cahya Nugraha, dan Herlawati "Sistem Pakar Tes Minat Dan Bakat Jurusan Kuliah Berbasis Android Pada Sma Islam Teratai Putih Global Bekasi", Jakarta Selatan, 2016

[7] Irwan Aditya Saputra, Joan Angelina Widians, dan Rosmasari, "Aplikasi Sistem Pakar Skoring Tes Iq Dengan Alat Cfit Berbasis Desktop", Universitas Mulawarman Kampus Gunung Kelua Barong Tongkok No.6, Samarinda, 2017

[8] Merry Christinne Steviani Adistiya, Januar Wibowo, dan Julianto Lemantara, "Sistem Pakar Penentuan Minat Dan Bakat Anak Umur 5-10 Tahun", Teknik Informatika Surabaya, 2010

[9] Prasetyo Adi Saputro, Catur Supriyanto,S. Kom, dan M.CS, "Analisis Metode Forward Chaining Dalam Sistem Pakar Diagnosa Penyakit Pada Hewan Sapi “, Jurusan Teknik Informatika FIK UDINUS, Jl. Nakula No. 5-11 Semarang50131,2010

[10] Sony Adams, dan Alfi Arifian, "Pemograman WEB", Yogyakarta, 2018

[11] Zulfian Azmi, ST., M.Kom, dan Verdi Yasin S.kom., M.Kom, "Pengantar Sistem Pakar Dengan Metode ", Jakarta, 2017 